Japan Institute of International Affairs (JIIA)

Founded 1959. Private, non-partisan institute committed to research on foreign affairs and security issues. Examines Japanese foreign policy, provides policy recommendations to the government and disseminates information on international relations to the public. JIIA aims to serve as an indispensable resource on international affairs.

Address: 3rd Floor Toranomon Mitsui Building, 3-8-1

Kasumigaseki, Chiyodaku, Tokyo 100-0013, Japan.

Website: http://www2.jiia.or.jp

President and Director General: Yoshiji Nogami.

\section{Kiel Institute for the World Economy (Institut für Weltwirtschaft an der Universität Kiel; IfW)}

Founded 1914. Independent, international centre for research in global economic affairs, economic policy consulting, economic education and documentation. Research areas: the global division of labour; knowledge creation and growth; the environment and natural resources; poverty reduction, equity and development; monetary policy under market imperfections; financial markets and macroeconomic activity; reforming the welfare society.

Address: Kiellinie 66, 24105 Kiel, Germany.

Website: http://www.ifw-kiel.de

President: Prof. Dennis Snower.

\section{Konrad Adenauer Foundation (Konrad-Adenauer-Stiftung)}

Founded in 1955 as the Society for Christian Democratic Civic Education and renamed in 1964. Political foundation that focuses on consolidating democracy, the unification of Europe and the strengthening of transatlantic relations, as well as on development co-operation.

Address: Klingelhöferstrasse 23, 10785 Berlin, Germany;

Rathausallee 12, 53757 Sankt Augustin, Germany.

Website: http://www.kas.de

Chairman: Dr Norbert Lammert.

\section{Korea Development Institute (KDI)}

Founded 1971. Think tank set up by the government aiming to make substantial contributions to the economic and social development of Korea. Research focuses on providing policy recommendations and guidance based on in-depth analyses of international and domestic economic conditions and projections.

Address: 15 Giljae-gil, Sejong, 339-007, South Korea.

Website: http://www.kdi.re.kr

Acting President: Kim Yong-seong.

\section{Korea Institute for International Economic Policy (KIEP)}

Founded 1990. Think tank under the affiliation of the South Korean government. The main function of the organization is to advise the government on all kinds of international economic policy topics. Research programmes focus on: international macroeconomics and finance; international trade; northeast Asian economies; Asia-Pacific; Europe, Americas and Eurasia.

Address: Sejong National Research Complex, 370,

Sicheong-daero, Sejong-si, South Korea.

Website: http://www.kiep.go.kr

Acting President: Kim June-dong.

\section{National Bureau of Economic Research (NBER)}

Founded 1920. Private, non-profit, non-partisan research organization dedicated to promoting a greater understanding of how the economy works. Concentrates on four types of empirical research: developing new statistical measurements, estimating quantitative models of economic behaviour, assessing the economic effects of public policies and projecting the effects of alternative policy proposals.

Address: 1050 Massachusetts Ave., Cambridge, Massachusetts 02138-5398, USA.

Website: http://www.nber.org

President: Dr James Poterba.

\section{Netherlands Institute of International Relations 'Clingendael'}

Founded 1983. Non-profit, independent think tank for international relations. Identifies and analyses emerging political and social developments for the benefit of government and the general public. Programmes include: diplomatic studies; European studies; security and conflict; international energy.

Address: Clingendael 7, 2597 VH The Hague, Netherlands.

Website: http://www.clingendael.nl

General Director: Monika Sie Dhian Ho.

\section{Peterson Institute for International Economics}

Founded 1981. Private, non-profit, non-partisan research institution devoted to the study of international economic policy. Research encompasses country and regional studies, debt and development, globalization, international finance and macroeconomics, international trade and investment, and US economic policy.

Address: 1750 Massachusetts Ave., NW, Washington, D.C., 20036-1903, USA.

Website: http://www.iie.com

Chairman: Peter G. Peterson.

\section{RAND Corporation}

Founded in 1948 out of US military research and development during World War II by Douglas Aircraft. Independent, nonprofit organization dedicated to promoting scientific, educational and charitable purposes for the public welfare. Research areas include health, education, national security, international affairs, law and business, and the environment. Houses three federally funded research and development centres sponsored by the US defence department: the RAND Arroyo Center, providing research and analysis for the army; the RAND National Defense Research Institute; and RAND Project Air Force.

Address: 1776 Main St., Santa Monica, CA 90401-3208, USA.

Website: http://www.rand.org

President: Michael D. Rich.

\section{Royal United Services Institute}

Founded 1831. Leading independent think tank engaged in cutting-edge defence and security research. The institution brings to the fore vital policy issues and offers expertise to policy makers. Principal research areas: defence, industries and society; UK defence; terrorism; nuclear weapons and nuclear arms control; cyber-security; conflict, war and culture.

Address: Whitehall, London, SW1A 2ET, UK.

Website: http://www.rusi.org

Chairman: William Hague. 